\title{
Pandemic Totalitarianisms, Limit Situations and Forced Vaccinations
}

\section{Papastephanou $\mathbf{M}^{*}$ \\ Department of Education, University of Cyprus, Cyprus}

*Corresponding author: Marianna Papastephanou, University of Cyprus, Department of Education, PO Box 20537, Nicosia, 1678 Cyprus, Tel: 0035799325183; Email: edmari@ucy. ac.cy

\section{Research article \\ Volume 4 Issue 4}

Received Date: December 12, 2021

Published Date: December 30, 2021

DOI: $10.23880 /$ phij-16000214

\section{Abstract}

In this article, I critically discuss the politics of forced and mandatory vaccination that is being now promoted in certain countries as a means for overcoming the Covid-19 pandemic. I canvass my critique through Karl Jaspers' notion of a "limit situation" and through references to Ionesco's plays Rhinoceros and Jeux de Massacre both of which concern hygienic, existential and political dystopias. My aim is to explore and chastise the pandemic totalitarianisms that are now spreading in the world and revolve around the "vaccinated versus the unvaccinated" polarization.

Keywords: Covid-19; Mandatory vaccination; Jaspers; Ionesco; Identity

\section{Introduction}

Karl Jaspers' notion of a "limit situation" (Grenzsituation) denotes an occurrence in life that confounds, discomforts and displaces individuals by exploding their cognitive, decisionist, affective, moral and existential illusions of control and certainty. When confronted collectively, a limit situation may normalize emergency measures and produce new divisions. It may also shatter consensus, security and trust in timehonoured authority. An abrupt change of circumstances that causes struggle, disorientation and unusual suffering or even deaths may constitute a limit situation. The current, Covid-19 pandemic typically qualifies as such a limit situation.

Limit situations contain ambiguous events, potentially disabling or enabling. Jaspers' conception of a limit situation invites a variety of philosophical receptions, challenges and implications, existential and ethico-political. However, so far, discussions of the current pandemic as a "limit situation" reflect only an existential or psychotherapeutic perspective [1] and are depoliticized. In this article, I broaden the notion's relevance to the pandemic by exploring the new politics authorized or enabled in Covid-19's name, a politics that disables democratic public life. I aim to critique the political dystopia that is currently being shaped especially through mandatory vaccination. Pandemic politics is critiqued throughout the article, as my account of "limit situation" unfolds, but the last section squarely focuses on totalitarianism and forced vaccinations. Echoing Antonin Artaud's [2] association of theatre with pandemics, I illustrate some of my arguments through two plays, which characteristically involve escalating limit situations. Eugéne Ionesco's Jeux de Massacre (Killing Game) [3] is a scathing, tragicomic anatomy of pandemic (of all demos) reactions to death and to epidemic politics in a town ravaged by a plague. His Rhinoceros [4] is inter alia about conformism, political pressure and a moralist, facile sense of duty through which control and compliance are secured. Described as a malady systemically preparing Nazification, pandemic rhinoceritis, the transmutation of collective thought into de-humanizing ideology, proliferates pachyderms (thick-skinned beings) impermeable to any questioning. 
After some preliminary comments on the public sphere, I engage with the echo of Jaspers' limit situation in our pandemic times, making audible, in Jaspers' parlance, "the new sound in an old thought" [5] (P. 4). I read "limit situation" in a way that reconstructs this Jasperian concept and critically responds to current circumstances. Then, I argue that new, pandemic totalitarianisms are looming beneath benevolent, protective, humanitarian and moralist responses to limit-situation-emergencies. Vaccines are only one, possibly important, part of a multi-pronged solution; ${ }^{1}$ their being considered a precondition of public safety and the only way of showing moral responsibility is part of the problem, not its solution. Neither public health is thus protected, nor is the political "health" 2 of the global demos thus advanced. Before I proceed, I tackle how totalitarianism comes up in a context of vaccinations that seems at first sight to be purely medical.

\section{The Public Sphere}

As is well-known, for Hannah Arendt, political life requires that diverse positions be debated as to their ideality and promise of a better world. Blind rule-following dehumanizes the citizen, up to enforcing and dispersing a banality of evil. It is not an "evil" of a Mephistophelian, essentialist-metaphysical badness of global players or of an Antichrist, such as conspiracy theorists rejoice in imagining. It is the evil of an automated, mechanical conformity and questionlessness that produces a limited and univocal public sphere prone to normalizing and accepting just anything. Like the rhinoceritis in Ionesco's play, a contagious, dehumanizing adaptability makes citizens accessories to all sorts of violence, from minor, quotidian failings to take the other seriously up to crimes against humanity.

The current limit situation has, in public and private agendas, introduced inter alia a new topic, Covid-19

1 On why this is so, see https://www.orfonline.org/expert-speak/ why-a-narrative-of-the-pandemicoftheunvaccinated-risks-prolongingthe-pandemic/ Amongst other things, the authors in this source write: "A drive that involves restrictions only for the unvaccinated-and a returnto-normal for all others-falsely suggests that the vaccine is a silver bullet". In fact, "a narrative that lays the blame solely on the anti-vaxxers, complemented by corona restrictions that target solely this group, will be deeply counterproductive and will risk prolonging the pandemic". The authors emphasize the following: "To be clear: both authors are vaccinated. The minute we were allowed access, we queued up to get our jabs in our respective countries. We cannot wait to get 'boosted"'. That both authors feel obliged to end their article with this eager assertion is yet another indication of how authors who dare question, even if cautiously and minimally, the official narrative feel the need to offer their "credentials" to the vaccine so as to stave off the charge of being "anti-vaxxers" and the labeling, even bullying, that follows if one dares so much as mumble some reservations concerning what has passed for unquestionable truth.

2 On why this notion of health needs the quote-marks and on their evoking the risks of medicalized politics, see, Papastephanou, 2021. vaccines, and a new division and socio-political category, membership in which is determined by vaccination. As it happens with most socio-political divisions, the vaccinated and the unvaccinated one is also marked by a "pathos of distance" [6]: a distance between logos and impassionate appeal to emotions and a social distance, a chasm, created by a class-producing pathos of radical differentiation ("negative difference") that "others" the interlocutor/co-citizen. Angst, fear and phobias are attributed to whoever asks searching questions about the effectiveness, safety and politics of the new vaccines. In Ionesco's Rhinoceros, the Logician (the ultimate figure of toxic generalization/universalization) states: "Fear is an irrational thing. It must yield to reason" (P. 10). The psychologization of reservations about the vaccine argumentatively leads nowhere since it can equally be applied to any uncritical supporter of vaccination as a phobic subject afraid of the virus enough to sacralize the vaccine as a deus ex machina. In this limit situation, fear and vulnerability may lead to deifying the authority of science in blind faith and religiousness towards it. Or, fear and vulnerability may cause just the opposite, an utter lack of trust. The psychologistic tarnishing of the other's position, whatever that position may be, also overlooks that, as a motivator for thought, some fear, either of Covid-19 or of the vaccine, may not be a bad thing after all. What decides it is the quality of the thought itself and the responsibility to others. In fact, it is responsibility that some vaccine-maniacs invoke to campaign for the vaccine as the only means for controlling the pandemic. But just as fear works both ways, the charge of irresponsibility can also be reversed: the unvaccinated who takes all precautions not to spread the virus may act more responsibly than the vaccinated who feels that the vaccine guarantees protection. Ironically, just as some anti-vaxxers do when they rally against the vaccine, some politicians or "virologists" of various kinds who preach vaccination forget the mask in public places among crowds of journalists or at their political meetings. ${ }^{3}$

I have elsewhere indicated [7] that the transmutation of the medically descriptive category of the "vaccinated and the unvaccinated" into a normatively loaded polarization has contributed to the thriving of various fascisms. This medical category is now populated, to some degree, by extremes such as vaccine-maniacs and paranoid anti-vaxxers. Their excessive pathos leads them to some forms of fascist mindset or attitude, subtle or glaring. But, in this article, and without under-estimating the significance of even-handed, fair treatment, I focus on those who have institutional power and thus are more responsible for risks of systemic, state/ supra-state (e.g., Europe)-totalitarianism. As many of those

3 While some anti-vaxxers do so because they deny the existence or risks of the virus, some of their opponents do the same thing because they wrongly think that, being vaccinated, they risk nothing. 
who have such power have proven to be vaccine-maniacs of little motivation to stave off totalitarian dangers, they will be the "protagonist" recipients of my critique; of course, not only those in power but also their opposition (parliamentary, academic, etc.) to the extent that it is also complicit in, or passive toward, the new, pandemic totalitarian tendencies. In Ionesco's play, even the character Botard (of leftist leanings) becomes a rhinoceros. The apathetic stance of political terrains that are least expected to be apathetic to totalitarian dangers is most alarming and will make many apolitical people seek something redemptive in pernicious populisms. Therefore, this article is about the politics of the vaccine and its promotion, not about the vaccine itself, which will be discussed head-on only to the extent that its partial effectiveness and health hazards ${ }^{4}$ affect issues of ethical responsibility in the name of which mandatory or forced vaccinations become legitimized. The article itself neither discourages nor encourages people to get vaccinated; ${ }^{5}$ it only problematizes the politics of mandatory/forced vaccination.

I focus unevenly on vaccine-mania also because it involves an additional, yet unperceived or, at least, nontheorized totalitarian risk: a tacit exculpation, beautification and depoliticization of the scientific identity. Whereas other identities are associated with egregious injustices and repugnant politics, the scientific (especially the medical) identity is presented, perhaps today more than ever, as the most innocent and harmless. Little is mentioned about experimental medical blunders that caused severe health risks even deaths and were eventually retracted; even less is remembered of medical active involvement in gruesome practices such as Sami population sterilization; gone is any memory of how Pedro Albizu Campos died ${ }^{6}$ and what "scientific" heteronormativity sealed Alan Turing's fate; German university "research" on Herero skulls is silenced; ${ }^{7}$ "scientifically" carried out environmental destruction and trampling over animal rights becomes sanitized. Certainly, the whole issue goes beyond identities. Moreover, that scientific identities have been as plundering and blundering as any other identity does not mean that all new scientific products (e.g., Covid-19 vaccines) are bad. But it means that they may not merit the blind trust that is now expected from global publics. True, some scientific/medical innovations unfairly

\footnotetext{
4 This partial effectiveness and health hazards will be meant in the minimal sense that is accepted by both sides; this will be the case for the most part of the article, because in some other parts of it, this minimalism will also be problematized.

5 These options should be explored by research projects in medical fields whose results, conflicting or not, should preoccupy the public sphere, and not by philosophers as self-appointed prophets.

6 Papastephanou, 2011.

7 Such research was contacted in early $20^{\text {th }}$ century to prove African inferiority. For more on it, see Papastephanou, 2017.
}

encountered conservative, phobic reactions. But it is equally true that many harmful scientific and medical innovations have regrettably been treated by humanity with too much receptivity and uncritical acceptance, to detrimental effect for nature or for generations of people.

Yet, now, complicities of the scientific identity in colonialism, Nazism and human exceptionalism are cast aside, while science is considered only in its merits for human life and depicted as disinterested, innocent and progressive. By contrast, the complicities of, say, religious, ethnic/national or party identities in violence are clearly visible and easily detectible. They are even exploited by systemic media when the coverage of news about demonstrations conveniently focuses on the most regressive slogans of those vaccine skeptics who are most vocal. Reducing all questioning of vaccines to a splinter of archaism, religious or other, long surpassed by societies proud to be at an advanced modern stage of "development" makes it easier to caricature just any interlocutor and be done with her. However, if any new totalitarianisms become not just epidemic (state-contained) but also pandemic in the future, consolidated through global measures, this may not be due to any of those identities that have traditionally been held responsible (and in most cases with good reason) for regressive ideologies and destructive politics. It may be due to the scientific identity that is now cherished most, even within post-humanist circles which, despite their attacks on humanism, have been irremediably modern in their elated, jouissance and objet petit $a$, scopophilic relationship to new technologies and scientific developments.

Whilst the endorsement of vaccines leads to rendering them uncontroversial and censoring all questioning, principles such as avoiding medical acts against a person's will, principles that used to block some totalitarian risks, are now being controversialized. As the Covid-19 limit situation unfolds, Ursula von der Leyen states that dialogue on compulsory vaccination in Europe should be promoted. ${ }^{8}$ Since the metonymic figure of Josef Mengele, that compulsory and involuntary, non-consensual medical acts on a healthy person's body should be avoided has, in the European imaginary and collective memory, become an uncontroversial issue. ${ }^{9}$ By asking to open dialogue on

8 Ursula von der Leyen's exact words: “It is understandable and appropriate to lead this discussion now - how we can encourage and potentially think about mandatory vaccination within the European Union. This needs discussion, this needs a common approach, but I think it's a discussion that has to be led." https://www.euronews.com/2021/12/01/ eu-should-consider-mandatory-vaccination-says-von-der-leyen

9 The usual counter-argument is that vaccines have always been exceptions to this rule; for instance, compulsory education requires that children get vaccinated. This argument is proof of faulty syllogism in many ways. Just to mention a few issues that this syllogism overlooks, regrettably briefly for 
it, von der Leyen controversializes it, i.e., she declares it debatable and negotiable. Whilst the European public space has waned to totalitarian effect by declaring vaccine safety and effectiveness uncontroversial, it dialogically waxes in the direction of controversializing the principle against mandatory vaccination - in a façade of "democratic" openness though, in fact, to fascist effect. Right after Austria authorized compulsory vaccination, Germany at the moment of my writing (November 2021) is also considering it. Prior to these developments, some countries have, on very poor medical arguments, ${ }^{10}$ imposed compulsory vaccination on medical professionals and suspended from related work the unvaccinated.

Furthermore, the political rhetoric/slogan (spread by officials in Germany and by the Prime-minister of Greece amongstothers)thatitisnowa "pandemic of the unvaccinated" has only promoted a demonization of unvaccinated people. This scapegoating, along with von der Leyen's initiating "dialogue" on mandatory vaccination, reflects uncritical reliance on "authority" (even a gendered one); a housewife in Ionesco's Jeux de Massacre states: "My husband says that those people live in total confusion, no morals, no traditions. In fact they say that's what they die from... confusion" (P. 4). Oxymoronically, since pandemics concern all people, not an exclusive category, the "pandemic of the unvaccinated" rhetoric/slogan makes Covid-19 a problem caused or faced by Others. The implicit contradiction is: if it is indeed a pandemic of the unvaccinated, if only the unvaccinated die, and if the vaccinated are truly vaccine-protected, then how could the argument that the unvaccinated show lethal irresponsibility to the vaccinated be supported? ${ }^{11}$ Marked by various Sartrean counter-finalities ${ }^{12}$ this rhetoric/slogan,

reasons of space: not all vaccines are compulsory; vaccines which do not offer full immunity and cannot deal with viruses that get transmuted and for which the 'wall of immunity' is infeasible have so far been optional; the technology of children's vaccines has been monitored for years and differs from the Covid-19 ones; the almost absolute effectiveness and minimal risks of traditional vaccines have eased their acceptance by people all over the world; limit situations that raise concerns about hasty decisions are not good contexts for imposing a new medical measure globally.

10 In reality, these arguments are disputed by many medical experts because they reflect contradictory, faulty syllogisms. The possibility of contamination of patients by vaccinated nurses or doctors who are not asked to provide rapid or PCR tests at work is fine, and the whole handling shows responsible, caring behavior! The possibility of contamination of patients by unvaccinated nurses or doctors, who nevertheless provide tests regularly, causes hysteria and is recruited as a token of irresponsibility of the unvaccinated to normalize their suspension of duties and their being left to survive unpaid for months.

11 A possible answer that the unvaccinated may prolong the virus' transmutations and lingering in the community is countered by epidemiologists who admit that transmutations also occur within the community of the vaccinated because the virus transmutes for reasons unrelated to how the antibodies are produced.

12 On this term, see Papastephanou, 2009. this epitome of officially authorized fake-news, contributes to spreading rather than controlling the virus by making the vaccinated believe that the pandemic does not concern them. ${ }^{13}$

At this juncture, various post-isms are showing alarming apathy concerning the "pandemic of the unvaccinated" rhetoric, despite the commendable sensitivity that they have shown in the past to operations of "othering" others, ${ }^{14}$ a sensitivity for which they have gained pride of place, selfindulgent, positive moral self-images and much academic visibility on which they have been capitalizing. A likely disengagement is displayed concerning the wholesale incrimination of the unvaccinated and their all being lumped together into the category of the "far-right anti-vaxxer". But, even if all the unvaccinated could accurately be described in such terms (which is nevertheless not the case), could this justify vilifying them or forcing them to be vaccinated? Does one's ideology constitute good reason for losing one's right to refuse a medical act on one's body? Respecting the others' rights and entitlement to a different opinion is precisely needed when the other is radically different from us. We are not consistently democratic when we respect only whoever agrees with us.

One wonders: could this silence and apathy of otherwise very vocal post-isms possibly be out of panic reaction and politics of fearing that the unvaccinated prolong the pandemic? Or is it the psychic discharge that comes from blaming another for unfulfilled desire in limit situations? Or is it, at least in some cases, out of calculated fear that the careers or fame of such post-scholars may suffer if they, nominally "progressives", become even remotely associated with a social category that contains even adherents to farright and religious end-of-world conspiracy theorists? ${ }^{15}$ Regardless of their motive, which should be cast aside if we are to avoid the risky tactic of moralist finger-pointing (against those who may be afraid of being contaminated or of damaging their profit-bearing progressive profiles), the

13 Here is how one scientific source deconstructs the "pandemic of the unvaccinated" slogan: "In the USA and Germany, high-level officials have used the term pandemic of the unvaccinated, suggesting that people who have been vaccinated are not relevant in the epidemiology of COVID-19. Officials' use of this phrase might have encouraged one scientist to claim that "the unvaccinated threaten the vaccinated for COVID-19". But, "there is increasing evidence that vaccinated individuals continue to have a relevant role in transmission". "It is therefore wrong and dangerous to speak of a pandemic of the unvaccinated". https://www.thelancet.com/journals/ lancet/article/PIIS0140-6736(21)02243-1/fulltext

14 Such operations that have been pertinently condemned are: homogenizing various others, consolidations of binary oppositions and polarization, overlooking intra-actions, etc.

15 Bad company may make them lose the badge of the "leftist" which they have appropriated and turned into a sesame word, instead of enacting it as a real life, consistent political stance. 
point is this: they have totally forgotten that the respect of difference on which most contemporary academia has capitalized is not respect of the other so long as she is the same with us. And if I have chosen a "sous rature" operation to allow visibility of incriminatory motive-seeking while also condemning it (other such operations will follow further in the article), it is because I wish to keep in view the ugly face of negative difference, the totalitarian risk of unreflective incrimination of "others", that is, to give contemporary postist moralists a taste of their own medicine.

\section{Jaspers' Notion of a Limit Situation}

Jaspers introduced the concept "limit situation" initially in his Psychologie der Weltanschauungen [8] and then in his Philosophie [9]. To ease semantic access to Jaspers' "limit situation", let me differentiate it from what Jaspers theorized as a "basic situation" (Grundsituation) [10]. A human being's basic situation involves the trans-historical, existential antinomian experience of searching in vain for unity and plenitude. Such basic situations are: death, suffering, struggle, finitude and guilt. In my interpretation, basic situations signify the universality and inevitability of limits that demarcate human existence and its (im)potentialities. Basic situations are called "limit situations" when they turn from generalities into actualities, become challenging, new givens of a specific, situated self and explode certainties and solaces.

From a phenomenological prism, there is this eidetic issue: what one is conscious of when one has consciousness of a limit situation? One's always existing within the confines of basic situations entails that limit situations emerge in consciousness as mere possibilities. For, without the distress of a limit situation, according to Jaspers, a person experiences the world from a variety of unquestioned shells. A shell (Gehaüse) is the kind of existential comfort or buffer zone that shields the self from various risks and of awareness of being-in-the-world. I metaphorize this as follows: though ontologically homeless (our identities are constructed, not essentialistically pre-given), we are existentially ostracoeid (shell-having/carrying). ${ }^{16}$ But, unlike snails or shellfish, we bear our home within us (a home that is not always at first sight visible to us and to others). Homely is the feeling we get from comfort zones. Homely is the self-assertion that we are loyal to our principles and consistent in our claims, a selfassertion we obtain when these are examined in abstraction or at a safe distance, occasionally a social distance, from a situation that concerns others (e.g., migrants, the poor, oppressed women, etc.). However, in a limit situation, our

16 Compare here Jaspers from the Psychologie der Weltanscauungen: „Das Gehäuse besteht nicht mehr, der Mensch kann nicht mehr leben, so wenig wie eine Muschel, der man die Schale genommen hat" (P. 181). principles and values collide. The other may now become the "cause" of our missing jouissance, e.g., of having our lives back.

Limit situations create choices that may even be tragic when they are not laughable. A latter case is when scholars who have built careers on defending asylum seekers' rights are now prepared to accept laws that force asylum seekers to get vaccinated (... or else!) for the host country to get its life back. It is an "else" that does not threaten any wealthy citizen or achiever (the scholars themselves, if any of them - highly unlikely as it may be - remains unvaccinated). For they afford to purchase their "freedom of choice" by paying the unvaccination fine and who, by having paid it, in the eyes of authorities, cease to spread the virus until the next installment of the fine. Apart from the laughably contradictory (and certainly no less cruel for that matter), there is also the tragic. In the current pandemic, stories about unvaccinated people advising a relative to avoid the vaccine, the relative dying of Covid and now the unvaccinated inhabiting the tragic limit of guilt, remorse and regret abound. Systemic media exploit these stories unlimitedly. ${ }^{17}$ Still, there are also stories that are censored by systemic media yet emerge in other sources, or in daily communication, and concern the opposite: one's inhabiting the limit because of exhorting a relative to get vaccinated, a relative whose sudden death burdens the conscience of the vaccine proponent. Especially in countries where such cases are strikingly under-reported, any suspicion of the vaccine causing the death is sneered and the dead person's families do not even have the chance to learn what truly happened. In both kinds of stories there is no legal liability of the adviser, but this does not make them less tragic. Both reflect motives of familial care and love that turned into tragic choices that burden a person ever since. True, responsibility to others, to protect them from contamination and to speak to them with parrhesia (if they are in positions of authority), is vital; but exaggerating or simplifying how we choose to enact our responsibility reflects a shallow ethic of control and obscures that, in a limit situation, people may also be at the inexorable mercy of chance.

Limit situations heighten consciousness and give us a glimpse of the Encompassing (Umgreifende), that is, of all that is inaccessible or unattainable (as yet, perhaps

\footnotetext{
17 Though they belong to the tragic, stories of unvaccinated people who died have been portrayed in some systemic media with hints of Schadenfreude and paraded in public view as proof of well-deserved suffering (in a "serves them right" underlying logic). In this dystopian world, stories of people who talked a relative into vaccination and then the relative dying a death suspicious of vaccine side-effects - a situation that also belongs to the tragic - are sometimes treated callously by paranoid antivaxxers in anti-systemic blogs, again in a "serves them right" logic.
} 


\section{Philosophy International Journal}

ever) ${ }^{18}$ But they can equally reinforce one's certainties or prejudices. All sorts of paths open up, some of them leading to Existenzerhellung (illuminating Existenz). It takes a leap (Aufschwung) to reach such paths, a leap outside the subject's constitution. With these terms, Jaspers accounts for discontinuity, break, transformation and dislocation, without investing limit situations with exclusively positive connotations or effects..$^{19}$ Leaps may be paralyzing or in the dark. One may be plunging into an abyss. Still, a limit situation may encourage Existenz as authenticity and transcendence. Limit situations have a disclosing operation (Freilegung) in revealing modalities of Dasein. But, to Jaspers, there is no guarantee of Existenz. A strong possibility is retreat in safe harbours, despite a limit situation striking blows on the Gehäuse (even temporally crashing it) and disrupting the quotidian unfolding of the subject (or collectivity, I add) as coherent narrative. A most relevant illustration I find in Ionesco's Jeux de Massacre. The irony in the dialogic exchange at the meeting of the medical advisors makes the passage worth quoting in length:

"FIRST DOCTOR Our knowledge is powerless.

SECOND DOCTOR Powerless with the cases we have had so far. Powerless today. We will no longer be powerless tomorrow.

THIRD DOCTOR To say that scientific knowledge is powerless will lead to mysticism, which is outlawed. Or worse, to agnosticism, which is condemned by the medical association, the chemists, the physicists and biologists, not to mention the public health administration and the government.

FOURTH DOCTOR It is not mysticism which has filled the streets with corpses, tens of thousands of corpses.

FIFTH DOCTOR It is not the medical profession either. People died because they did not follow the rules for hygiene we established" (P. 85).

[...]

"FOURTH DOCTOR In other words, ladies and gentlemen, you maintain that hundreds of thousands of people are dead because of ignorance, stupidity, or because they were unable to believe in the truth

18 Having a glimpse of the abyss of the encompassing heightens our sense of the limits of our epistemic achievements and allows a more accurate image of human finitude. However, a transformed ontology is in truth impossible. The multiplicity of the modalities of the encompassing (that Jaspers denotes with a Greek term, "Periechontologie") remains suspended. ("Eine neue Lehre vom Sein (eine verwandelte Ontologie) ist in Wahrheit unmöglich geworden, ein Entwurf der Weisen des Umgreifenden, worin wir uns finden (eine Periechontologie), muß selber in der Schwebe bleiben". See, Jaspers (1967, p. 83).

19 That is, Jaspers does not normativize or glorify limit situations, as we sometimes notice occurring in some post-structuralism concerning the related notion of limit-experience. of our credo.

FIFTH DOCTOR We can attest to it. They became vulnerable to the counterpropaganda and thus its victims. It is because of that very propaganda that our science is helpless. The victims are the ones responsible in fact; they should have believed us. Unfortunately for them, they held to another belief, old, out-of-date to be sure, but virulent nonetheless" (P. 88).

Concerning our current pandemic, "a perfectly understandable response", David Black writes, is "the immediate practical issue: how to limit infections and the death rate and protect the population, and yet keep the economy functioning"; all in all, "this is the urgent and necessary issue, and many people, eager to get back to normal, might say it's the only issue" [11] (P. 11). Against such a Gehäuse reaction, Black registers another possibility: to treat the Covid-19 crisis as a wake-up call. Without minimizing the "seriousness of the crisis", we should look beyond it and learn from it to revisit rather than restore the previous normalcy. I agree, but I would also register yet another response, one that considers a danger less visible though no less immediate than the health danger: that of this limit situation leading us to losing some good principles and counterfactual possibilities of post-war ethico-politics. These should be neither romanticized nor surrendered to totalitarianisms of either side of the "vaccinated-unvaccinated" divide. Whereas wake-up calls involve warnings about what has gone wrong (climate crisis, etc.), and are valuable, they overlook that democratic gains may now be at risk and that bad things can also come from there where you least expect them.

Jaspers avoids prescriptivism concerning how to cope with a limit situation. He nevertheless authorizes a general response to such a situation that involves a transcendence which is not an overcoming. He also authorizes a subjectification process: the "meaningful way for us to react to limit situations" is not "by planning and calculating to overcome them but by the very different activity of becoming the Existenz we potentially are; we become ourselves by entering with open eyes into the limit situations" [12] (P.179). Yet, subjectification does not entail, for Jaspers, "subjectobject" relationality to the world: becoming Existenz means a heightened relationality in existential communication and in "loving struggle" (liebender Kampf). ${ }^{20}$ "Loving struggle" signifies, for Jaspers, "a wrestling with the other to press other and self further than either has been able to go alone" [13](P. 113) - an ethical attitude that, I believe, avails itself to important politicizations. By contrast, our limit situation is marked by absence of a well-judged affectivity, deliberation (especially of public debate) and agonistics. Missing is also

20 For more on the notion of "loving struggle", see Salamun (P. 320). 
the ethic of dialogue that treats: dialogue as possibly will/ opinion-formative; the other as capable of justice; and the self as a truly engaged interlocutor who may be enlightened by others rather than only enlightening them. Just as in Ionesco's Jeux de Massacre, nowadays, concerning vaccines, "someone who thinks differently from you is your enemy" (P. 30), an ideologically contaminated/contaminating, cumbersome Other: "FIFTH DOCTOR Bad examples are contagious. SIXTH DOCTOR The living masses are stupid enough to follow bad examples. We shall enlighten them" (P. 89). And in Rhinoceros, "here is an example of a syllogism. The cat has four paws. Isidore and Fricot both have four paws. Therefore Isidore and Fricot are cats" (P. 18). Now, a similar irrationality masked as syllogism is: conspiracy theorists question the vaccine; you question the vaccine; therefore you are a conspiracy theorist. Such twists of reality misapply logic to totalitarian and scapegoating effect and render toxic the human need to generalize, universalize and deal with the "pandemic" character of logical conclusions.

Limit situations are bound up with excess. They reveal the exhaustibility of human power and of one's ability to cope by habitual means ${ }^{21}$ with the abysmal force of challenges within our inescapably spatiotemporal situatedness, in our being singular existences, though entangled with one another. By being there for us to endure and transcend them, by being inexorably ours, limit situations, tragic and defining, disclose the persons that we have become, while simultaneously reshaping us, reshuffling our fabrics and restructuring our relationships, sometimes leading us to forming new, likely and unlikely alliances. Limit situations are constitutive of subjectivity: "What I would be without those situations becomes an empty conception; it is in them that I am myself, as the phenomenal body of what I can be. In the limit situation, transcending any comprehensible thought, I experience myself - shaken, first, and then as one with chance, which I take to be mine" [12] (P. 191). Thanks to them, we become aware of an existential (i.e., non-exclusively cognitive/rationalist) universality, a pandemy inherent in being-in-the-world: in principle, everybody can be affected by a traumatic limit situation and everybody is destined to experience limit situations at a given time. ${ }^{22}$ Still, beyond

21 The shock effect of a challenge whose source is invisible, the claustrophobic ambiance that extreme, militaristic emergency measures create and the realities of encampment/entrapment which are then consolidated are evoked in Ionesco's Jeux de Massacre thus:

"We are being devastated by a plague without visible cause. I must advise you that neighboring countries as well as towns have barred their gates to us. Soldiers surround our city. No one may enter and none of you may leave. Yesterday it would have still been possible. But as of today we are trapped" (P. 18). Let me here add that I consider states of exception and camps as spaces relevant to limit situations and let me remark that theorizing them in connection to the notion of limit situation may constitute new, fertile ground for ethico-political philosophy.

22 I consider this Jasperian idea a major possible contribution to
Jaspers, how such a situation is experienced is marked by divisions that precede those created by the limit situation: class, race, gender and other singular positionings diversify how a person responds to emergency measures ${ }^{23}$ and open the path to politicizing the limit situation more deeply.

\section{Echoes and New Sounds of Limit Situations in a New Situation}

"The truth of present-day philosophy manifests itself less in the formation of new fundamental concepts", for instance, "limit situation", "than in the new sound it makes audible for us in old thoughts". Jaspers, who wrote this in a self-reflective text entitled "On My Philosophy" $(1941,4)$, asserts that his truth lies more in his addressing old philosophical debts than in his introducing new concepts such as "limit situation".

Jaspers' aphorism separates coinage from temporal circulation of ideas. Yet, there is, I think, a more complex interplay of the two philosophical truth-manifestations, i.e., conceptual innovation and acoustic attentiveness. As I see it, new thought erupting into the world and one's harkening to the past (or dialogical reverberation of the old in the new) are sometimes almost inextricably intertwined, as the former is born by the latter. For example, Grenzsituation (limit situation), a concept that Jaspers valuably introduced into the philosophical world, was nevertheless a manifestation of his own, original synthesis of older sounds such as Immanuel Kant's Grenzbegriff (limiting concept), antinomies and transcendence [14] (P. 39), which, through Jaspers' rearticulation, were made to speak a different and impassioned idiom. In this article, my attempt is to make audible precisely what I sense as a new sound in Jaspers' - by now old and largely neglected - thought on a "limit situation". Hence, after reviewing the term's echoes today, I associate it with the current pandemic in a way that is descriptively faithful to Jaspers' philosophy and reflects how I read it. I retrieve "limit situation" to make a new sound of it audible for us and simultaneously critical of our new philosophical hegemonies and complacencies.

Therefore, my aim is not to "update/upgrade" Jaspers' thought. A philosophical tendency toward (to use a Greek

discussions concerning universalism. A conventional wisdom of postmodern times has it that universalism is an inherently negative and politically pernicious concept. I think that such certainties and the complacencies that they further enforce can be challenged from a perspective that, though critical of some of Jaspers' ideas, pays nevertheless attention to those of his insights that redirect discourses on universalism and allow us to perceive its ambiguities.

23 For example, an immigrant, a pensioner, a low-income, part-time, or unemployed person may not have the luxury to pay the punitive, monthly fine in Greece that the conservative government of Kyriakos Mitsotakis has imposed on those over 60 years of age who do not wish to be vaccinated. 
word) "epikairopoiisi" ("updating/upgrading", making something up to date, catching up with time qua kairos, opportune time, and simultaneously synchronizing it) has, I argue, the following downside. The thought that is "updated" becomes attuned to the spirit of the times (Zeitgeist), e.g., to "our" viral, pandemic times, and regains some life by becoming merely ancillary to what has already passed filters of hegemony. It comes to join a constellation of established ideas to enhance them or further to verify them. Such a downside may be avoided or, at least, mitigated by harkening to the older thought's renewed possibilities of playing a more active, critical part in a philosophy that should be more cautious of its own complicities and consolidations of new master discourses.

Concerning echoes, let us see how Jaspers' limit situation survives (or not) current philosophical "partages du sensible" (distributions of the sensible, to adapt Jacques Rancière's well-known term). Current intellectual choices concerning Jaspers and his notion of a limit situation vary. In my view, perhaps just as all scholarly choices, these also reflect inter alia existential decisions of the scholars themselves. They reflect, for instance, the scholars' highly personal identifications, fixations, and comfort zones, Gehäuse, related to identities cherished or condemned, and to scholarly unwittingly/unconsciously metaphysical reverence to philosophical avatars and ethico-political, affective and cognitive investments in theoretical camps. ${ }^{24}$ Ultimately, they reflect wider contextual, socio-political and theoretical sedimentations.

The concept "limit situation" is still a point of interest in philosophical circles of existentialist, phenomenological and hermeneutic leanings, but the broader influence of such circles has extensively diminished for reasons too many to account here. ${ }^{25}$ Yet, "limit situation" has made a comeback in German psychological and psychotherapeutic circles. ${ }^{26}$ It has also appeared in the field of communication studies ${ }^{27}$ along with Jaspers' conception of "existential communication". However, political philosophy has, with too few exceptions, ${ }^{28}$ bypassed Jaspers' notion of a limit situation. In educational political theory, Freire's ${ }^{29}$ reformulation of Jaspers'

24 Having said that let me clarify that I do not imply a normativity of engaging with Jaspers. Nor do I imply that lack of interest in Jaspers is reducible to concerns of vogue, popularity and academic visibility.

25 Just indicatively, one reason is the polemics against existential philosophy (and against existentialism) by rivals as diverse as the Frankfurt School and the poststructuralist camp.

26 For instance, Fuchs, 2013 and Mundt, 2014.

27 For instance, Gordon, 2000.

28 For instance, Gatta, 2008.

29 For instance, Freire's Pedagogy of the Oppressed (P. 99). To Freire, limit situations are those existential situations that limit human potentiality and "limit situation" has been overlooked. "Limit situation" is surprisingly neglected (even missing) in educational studies of emotions and trauma, in peace education and in conflict resolution initiatives, especially in those that callously overlook the situation of the conflicting parties and depoliticize reconciliation by reducing it to individual psychology.

In post-structuralist circles, the exaltation of "limitexperience" 30 has blocked attention to "limit situation" although the latter constitutes much more fertile relational ground for theorizing a care of the self than the former. The otherwise commendable postmodernist attacks on authenticity, humanism, exceptionalism, eurocentrism, metaphysics, etc., attacks which offer pertinent points of critical entry into Jaspers' thought, nevertheless, block the interest in Jaspers. They have even blocked awareness of postmodernist affinities with Jaspers' rejection of closure and plenitude and emphasis on finitude, situatedness, contingency, and shattering. Jaspers claimed that "any clearly stated theory of the whole, whether religious or not, becomes a shell protecting human beings of the original experience" of limit situations [15] (P. 39). Ironically, Jaspers' notion of limit situation has failed to attract poststructuralist attention precisely because this notion is part of a whole that post-structuralism rejects and because post-structuralism, despite protests to the opposite, has blatantly become a shell (Gehäuse) and a master discourse whole. Transmuted into theories of the whole (grand-narratives and master discourses), post-structuralism and post-humanism tend to reject whatever causes cracks or upsets their tenets.

I politicize limit situation also by indicating how institutional power creates, for more vulnerable subjects, limit situations within the broader limit situation of the times. But, a word of caution concerning aestheticizations of limit situations: "Limit situation" could resonate with a Lebensphilosophie sweeping incrimination of bourgeois normalcy and of (supposedly) "petty virtues" and with a concomitant glorification of a modernist, exceptionalist aesthetic of shock. A fascination with limit situations as "unique moments of existential peril that become a proving ground for individual authenticity'” [16] (P. 432), in my opinion, diverts attention from the ethico-political demands that the inexorable specificity of the other's limit situation ${ }^{31}$

have to become known and overcome.

30 In my view, the "limit-experience" that has gained so much more popularity in educational philosophy is a much "safer" and tension-free notion, far more monologically fascinated with the epiphanic than Jaspers' limit situation.

31 I have illustrated this above with the example of the migrant and elsewhere (Papastephanou, 2021) with the working mother forced into vaccination in a "jab for job" logic. 
makes on us. As Wolin valuably shows, the "aesthetics of horror" (Aesthetik des Schreckens) sets the lifeworld on one side, and "suddenness" (Plötzlichkeit), rupture and discontinuity (433) on another side. The one pole is incriminated; the other is invested with redemptive force. Some "wake-up call" approaches to the Covid pandemic face, precisely though needlessly, this risk. The "society of 'normalization' (Foucault) must be subjected to an 'aesthetics of rupture'", where "the exception enters the scene, for the exception alone, qua borderline concept (Grenzbegriff) allows the power of real life"' (433). ${ }^{32}$ My discussion of "limit situation", then, should be read against such thanatoptic and thanatourist, deep-down apolitical, outlooks on the other's tragedies. Such outlooks become, I argue, a self-exculpating and complacent, new hegemony that makes common cause with its supposed opposite, i.e., with moralist, philanthropic and charitable stances toward the suffering other that emphasize urgent, problem-solving logics of returning to previous, precious normalcy. ${ }^{33}$

For Jaspers (1971), we tend toward stability and quiet because we cannot bear the infinite vortex of the relativization of all concepts. His is a psychological-essentialist objection to relativization, whereas mine would be an ethico-political one. It is sometimes the other's limit situation (and the demands it makes on us) that resists relativization. For instance, combating the controversializations of the principle against compulsory vaccination that relativize all related concepts requires concepts (truth included) as leaning points. We sometimes rely on concepts not because, supposedly, we cannot bear relativization psychologically, but because we find relativization ethico-politically amiss and repugnant. Contrary to Jaspers' assertion ${ }^{34}$ that conceptual stability shields us from limit situations, I argue that, sometimes, conceptual stability precisely enables a glimpse of a limit situation. It even helps us acknowledge the limit situation that the other is in. In so doing, it shatters the shell (even if temporarily) that blocks insight into the other's limit situation, a shell which is especially strong in cases where the other's limit situation remains unperceived precisely because we (individually or collectively) have created the other's limit situation. The dilemmas and conflicting loyalties that measure such as forced vaccination creates and which vary as to how they produce limit situations within a broader

32 I agree with Wolin regarding the dangers of such an approach to limit situation, but I see them as more traceable in conceptions of limit-experience than in Jaspers' notion of a limit situation.

33 Such logics aspire to "save" the lives of others by saving them from themselves in the modality that became well-known after the multi-state, "pandemic" invasion of Iraq in 2003. It is the modality of preemptive action which, in this context, takes the "lighter" form of forcing the unvaccinated to get vaccinated before they get contaminated or contaminate others.

34 Also, contrary to postmodernists who would agree with Jaspers on this point. limit situation on grounds of social divisions and inequalities resist conceptual relativization precisely because of their ethico-political effects. Conceptual stability further invites perseverant, consistent and persistent commitment to ethico-political principles.

A major ethico-political issue is that generalities of existential vulnerability turn through action (or lack of action) into concrete, distressing experiences for unevenly positioned, situated people or for nature. ${ }^{35}$ The current hegemony of power and biopolitics as tools explanatory of operations that are productive of subjectivities could be critiqued through awareness of limit situations as simultaneously produced by and productive of subjects, thoughts and worlds. ${ }^{36}$ In critical dialogue with Jaspers' philosophy we may also rethink our grasp (and related failures) of concrete human positioning. Jaspers exhorted us to enter our limit situation with open eyes. However, I argue, (post-)modern philosophy ignores this exhortation when it enters the current pandemic with eyes closed to the other's limit situation, especially there where philosophy seems to be at its most attentive, that is, when it abstracts, romanticizes, aestheticizes or ontologizes the other as "the migrant", "the refugee", "the underprivileged" , "the dissident", "the destroyed nature", etc. Mandatory vaccination is met with too few questions by European publics in the name of "solidarity" and "working together" to overcome the pandemic. These "inclusive" slogans have proven exclusivist in failing to cover also the unvaccinated who lost their jobs despite their not endangering others more than the vaccinated do. These slogans were also short-lived, if we consider how limited were the numbers of vaccines affordable by nonEuropeans or how some Europeans reacted to the Omicron transmutation coming from some African countries. Current European limits to "solidarity" are strikingly reminiscent of Ionesco's Jeux de Massacre:

"PIERRE The disease, in the city. The epidemic raging in the slums.

\footnotetext{
35 Jaspers' nuances then help us define cruelty - in its opposition to misfortune (or disaster) - as a human-made transformation of a basic situation into a limit situation for specific human or non-human others. Let me respond to a possible objection here: one may think at first sight that limit situation is by definition (at least Jaspers' definition) an exclusively humanist term; but I do not endorse this "first sight" assumption. Though non-human otherness may not experience a limit situation as humans do or, if the non-human otherness belongs to non-biota, it may not experience it at all, the term and concept nevertheless remains relevant because as such, and as I theorize it in some critical distance from Jaspers, is not reducible to consciousness. It has aspects of an objective category, regardless of how or whether it is lived out by those affected by it.

36 This point definitely needs much further development but, for the purposes of this article, I merely state that limit situations as ethico-political explanatory tools, and not only as lived experiences, help us obtain insight into elements of human existence that are not reducible to power relations, even if the latter play an important role in these situations.
} 
EMILE The slums is where it's staying, dear boy. Here we're safe. The slums are, well you know, ignorant ... JACQUES Unhygienic ...

EMILE Teeming with vice ... and poverty, of course. JACQUES Yes, you can't underestimate poverty . . . nor squalor. Squalor is a filthy thing" (P. 47).

"PIERRE You really think it won't reach us?

EMILE I can't see how, we're neither poor nor ignorant" (P. 48).

My ethico-political perspective on limit situations focuses not only on those that humans-as-subjects encounter but also on those they create for themselves, others and nature. True, limit situations befall the subject; but it is also true that some do not fall from the sky. And some have an unavoidably collective dimension. They are the limit situation of a specific "we". Thus, alongside the centrality of the limit situation for the subject, I see another potential centrality: that of approaching the ethico-political limit situations that others face, or we create for others, and remain overlooked in the generality, the "pandemic" abstraction, that determines our theorizing them. The immigrant, the refugee, the rooted subject stuck in a war zone ${ }^{37}$ experience a limit situation within a broader, global limit situation (again, in unfathomable variety, subjective singularity and irreducibility). Western subjects who partially perceive or overlook such others are in their own political Gehaüse.

To Jaspers, limit situations are also sources of philosophy. "Jaspers identifies three sources of philosophy: wonder, doubt, and 'ultimate' situations", yet "wonder, doubt, and grappling with ultimate situations are not enough", for "they can operate only if there is communication among people"' (Gordon, 2000, P. 113, quotes Jaspers). A caveat here: a problematic possible implication of Jaspers' connection of philosophy and limit situation is that, confronted with a limit situation, a subject may resort to philosophy for solace rather than for truth. Or, philosophy could succumb to a problemsolving idiom rather than to a question-raising one. By saying this I in no way mean that the world should not resolve the problem of Covid-19. But problem-solving operations should be undertaken by a medical science that will concentrate on its tasks without aspiring to medicalize the political, become kerygmatic or dominate the political sphere and answer also political rather than medical questions. Philosophy should be question-raising there where the public sphere, in panic reaction, takes everything for granted or arms science with unprecedented and unmerited political power. As I see it, this so overlooked point is extremely significant for a meta-

37 Even if/when facing their own private, epidemic or pandemic limit situations, Western subjects do not experience the political limit situation within the broader, "pandemic" limit situation that, say, a "war zone" subject experiences. philosophy that explores what lies between problem-solving and question-raising. ${ }^{38}$

However, this possibility should not obfuscate another relationship between philosophy, truth and limit situation: that of the other's limit situation setting in motion philosophy's truth-seeking operations. We stand with eyes closed in front of the others' limit situation when our knowledge of the extent of human entanglement and its concatenated effects on collectivities is limited. ${ }^{39}$ With a limit situation "a truth about one's Existenz enters suddenly into consciousness - a truth that, more often than not, is unbearable for those affected" [17] (P. 2). Not just a truth, not just a moment of realization; the challenge is more multiple than a monological frame allows us to perceive. Limit situations also effect a tension of action, an impasse, impossible choices, tragic ethical dilemmas. In my view, Jaspers' limit situation could be thought through beyond his own association of it with fundamental conditions of Dasein. In other words, I see a surplus of possible significations of the term and possible instantiations beyond those of struggle, guilt, chance and suffering, though inclusive of them. Limit situations can also be conceptually demarcated by a void and a necessity, an absence and a presence: in a limit situation, the person has to make a choice and decision without a traveler's guide, scientific authority guidelines, etc., and in urgent need for non-deferrable action. In some cases, this action may be monological - in the sense of being just the creation of a new world orientation for the self. The protective shell is missing and a new home is to be searched

38 Though problem-solving and question-raising should not make a neat distinction, and realities are usually fuzzier than theoretical categories, the distinction itself could be politically useful. Problem-solving is sometimes attributed to philosophy by (neo)pragmatism but it strikes me as impoverishing of philosophy. It domesticates philosophy by seeing it as oriented to issues that have already cropped up in the lifeworld and require solutions. Against it, and following ancient theorizations of philosophy, we may emphasize question-raising and aporia. That is, philosophy problematizes precisely what is un-problematic in a lifeworld, i.e., all those things that appear not to require solutions. Therefore, philosophy raises questions precisely there where people are immersed in certainties. However, in-between problem-solving and question-raising, there seems to operate philosophy also as response to limit situations. From a philosophical perspective, rather than from a social or scientific perspective, limit situations do not invite problem-solving. In fact, they are outside the register of problem-solving. As sources of philosophy, limit situations are, in my view, inter alia concretizations of existential, ethical and political questions, even aporias, and thus also potentially corrective of our epistemic, self-reflective perspectives on philosophy.

39 By this I do not mean the well-rehearsed argument of some poststructuralist and activist circles, with which I strongly disagree, that supposedly, if we are not in the position and culture of another person we are not entitled to speak. I rather mean that the tendency within discourses of empathy to focus on the subject and her emotions harkens to the situation of the other only indirectly (to the extent that the situation may have emotive effects observable or imaginable from the point of view of the sympathizer), thus failing to grasp the multidimensionality of the situation as such. 
within the confines of a differently illuminated existence, one of awareness and reconciliation with human finitude and vulnerability. But, in some limit situations, another kind of action is urgent, a relational one that directly affects the lives of others. A limit situation (one's own or another's) is both a terra nova and a tempus terribilis, hic abundant leones, ${ }^{40} \mathrm{de}-$ territorializing and inviting extra territorium jus, a law and 'justice' out of the ordinary, and there lies a major danger for post-II world-war Europe and beyond.

\section{Hic Abundant Leones: Pandemic Totalitarianisms and Forced Vaccinations}

In Rhinoceros, rhinoceritis spreads and increasingly becomes a new normality and normativity. Nobody should fail to become a rhinoceros, if solitude is to be avoided. The move from the public to the private ${ }^{41}$ evokes the dehumanizing, pandemic internalization of totalitarian spirit. In Jeux de Massacre, "anyone entering a sick house becomes a suspect and will be incarcerated in that house. Be on the watch for suspects. Report them in the interests of the public !". "Every contaminated house will be marked with a red cross one foot high on its front door with this inscription" (P. 19). In our pandemic limit situation, the totalitarianism of mandatory/ forced vaccinations that is now spreading from one country to another has been facilitated by safe pass surveillance, brainwashing and demonization of the unvaccinated.

Limit situations are uncharted waters. Following Jaspers, Matthew Ratcliffe theorizes one sense of going adrift, in a limit situation, as "losing what was habitually taken for granted, with the consequent removal of norms that once guided activity and thought" [18] (P. 2). One such norm that he does not consider is the norm against mass scale medical acts on unwilling subjects. He considers the growing lack of trust by segments of the public, but he does not discuss this: if it could ever be justified, blind trust should at least be somewhat merited and earned. Do the ways in which vaccines have been promoted build trust? Some unvaccinated people emphasize that these vaccines got expert approval as an emergency measure and that they will remain at testing stage until 2023. Therefore, these people feel that, by forcing them to get vaccinated, governments submit their health to a gigantic experiment. On this they are wrong, for things seem far worse. To merit the term "experiment" a scientific process requires monitoring and testing of results - in this case, ongoing pharmakovigilance. That the current situation involves much under-reporting of vaccine side-effects and limited submission of yellow cards, especially in some

40 'Here lions abound': a phrase written on uncharted territories of old maps.

41 From outdoors scenes the play Rhinoceros gradually moves into indoor spatiality. countries, hardly qualifies it as an experiment. Even if the vaccines are effective and safe, which is an issue beyond this article, the way they have been pressed on societies smacks of ideological, blind faith, pseudo-science and charlatanism.

Interestingly, vaccine good tolerance has proven to be astonishingly national-identity-dependent: European data of reported cases of vaccine side-effects by country indicate that, say, the Greek body miraculously agrees with Covid-19 vaccines more than, say, the Dutch body. Dying of vaccine side-effects or being a breakthrough case in hospital or deathbed is effectively forbidden in Greece and Cyprus. Those who disregard this and insist on dying are excluded from the domain of officially authorized news. Besides, Greece and Cyprus have given their fully vaccinated citizens their life back (with no regular testing or restrictions such as those imposed on the unvaccinated). Fully vaccinated citizens are prohibited from contracting Covid-19, and this governmental prudence has admirably produced a success narrative constantly ruminated by systemic media. ${ }^{42}$ Statistics of death by Covid-19 of the fully vaccinated showed understandably lower numbers than those of other countries, and all that remains for Greece to snap out of the Covid-19 predicament is to force all the population into vaccination. In reality, one complication of this success narrative is that, compared to countries that have strikingly lower numbers of vaccinations, Greece has twice their number of deaths by Covid-19. Another is that, despite the governmental banning of vaccine side-effects or vaccine ineffectiveness, these stubbornly defy it. They keep occurring and, despite their not being mentioned by systemic media or commented on by officials, they find a word in edgeways through personal narratives and communication of people or through other avenues. Here is Ionesco, sardonic in Jeux de Massacre: "PUBLIC OFFICIAL The administration never hid the truth from you. During the worst hours, we always provided the true figures. We never hid the exact number of the dead and dying. We did all that was possible to combat the disease by taking drastic steps, unpopular steps. We have no reason to lie now" (P. 106).

In our pandemic limit situation, rationalizations, excuses or pretexts for imposing totalitarian emergency measures ${ }^{43}$ invoke slogans such as "There Is No Alternative" and "We Have No Choice" if we are to protect public health. Is it true that there is no choice? In one of his interviews, ${ }^{44}$ Margaritis

42 It will be surpassed and the situation will be much better and safer only if the unvaccinated will come round.

43 In this article too, as I have done in another (Papastephanou, 2021), I stress the colonial echoes of a state of emergency.

44 https://www.youtube.com/watch?v=xSV63BhqoHs\&ab_ channel=SKAIRADI0100\%2C3FM Margaritis Schinas is a member of the New Democracy party (right-wing) of Kyriakos Mitsotakis (Greek Prime 
Schinas has blithely stated that Europe has approved about eight medications, effective against Covid-19, and that, for a whole year now, countries can buy them. Europe has made no such provisions (that would have even reduced the price of these medications to make them more state-affordable) because Europe wishes first to complete the vaccination program!!! These ideas must have also been stated by other European officials and must be no secret. Why have they not caused controversy and intense communication of people in Europe? Greece has only very recently bought too few monoclonal therapies and, to my knowledge, Cyprus has not yet ordered any. Thus, the liabilities of the "pandemic of the unvaccinated" slogan go beyond the official fake news of getting one's life back, if vaccinated, returning "safely" to normality and facing no life-threatening Covid contamination. For instance, concerning a 36 year-old person who died of Covid in Greece, though fully vaccinated and with no underlying illnesses, one question would be: would he have had more chances to survive had Europe not exclusively prioritized the completion of the vaccination program and had Greece not followed a similar policy? More generally, how many people around the globe may have died because of this peculiar fixation that no multi-pronged approach to Covid-19 should be allowed? How betrayed the paradigmatic, dutiful citizens who got vaccinated must be feeling by their governments and the lack of back-up measures that would have truly protected them from hospitalization (and possible death) in case they were the unlucky ones for which the vaccine did not work as promised? How close to "selling-out" is the euphemism "completion of a vaccine program"? What does "a crime against humanity" stand for? I do not have the answers to these questions but this is precisely the point: in non-totalitarian public spaces such questions are openly and constantly debated. They are not left to be answered arbitrarily by the individual. But von der Leyen is eager only to open the dialogue on compulsory vaccination.

For Ionesco, as he clarified in an interview, ${ }^{45}$ rhinoceritis is "l' esprit totalitaire". Nazi Germany was one instantiation of rhinoceritis' modalities ascending and spreading. The rhinoceros are not the masses ${ }^{46}$ but what Ionesco calls in his interview the "demi-intellectuals" or "professional intellectuals" ("writers, journalists, professors and the like") and hypostatizes in his plays as politicians, logicians, doctors,

Minister). He is a vice-president in the Von der Leyen Commission with the portfolio of European Commissioner for Promoting the European Way of Life.

45 https://www.youtube.com/watch?v=yjRiTGS8n3c

46 As the interviewer remarks, this is a novel idea because people always say the opposite, and critics have interpreted Ionesco's Rhinoceros as the masses, to which Ionesco responds that: 'ce ne' est pas la foule, ce l' esprit totalitaire", and the play serves as a trial of intellectuals. Ionesco specifically mentions those who were "Nazis before the war, and in France they were very fascist, and now [post-war] they are leftist because of power". judges, attorneys, etc. He justifies his anti-intellectualism not as an allergy at everything intellectual but at something very specific: he does not like demi-intellectuals because "they don't really think. They only think they do. They simply repeat slogans. They succumb to superior slogans". I am not using Ionesco's charges as another category to be consolidated and to produce negative difference by singling out particular groups as supposedly more contaminable and simultaneously more infectious vis-à-vis totalitarianism. Nevertheless, Ionesco unmasks intellectuals as characterized by mass mentality, while also indicating that asking too few questions makes totalitarian tendencies thrive. His plays uniquely reveal how, in limit situations, no social category or ideology is immune to totalitarian risks.

Because totalitarianism concerns inter alia the limited debate-ability of topics in public discourses, the current limit situation operates politically also by determining what passes for (un)controversial in the current European or global mindscape and deliberative processes. Against the current treatment of "universalized" vaccination (pan-demic qua vaccination of all demos) as scientifically uncontroversial, some medical experts claim that vaccination is more suitable when a pandemic has subsided; until then, medication is a more appropriate means for saving lives, and masks (along with other, target-differentiated measures), for controlling the pandemic. Such positions are censored from the public sphere in most places. As this article is political and not medical, and my expertise is political philosophy, and not medicine, these contrasted positions of experts are not mentioned in order to be adjudicated but only to indicate the controversial character of political decisions to extol vaccination as a singular means for dealing with the current pandemic. Apart from requiring adequate testing, a new scientific development such as a vaccine also requires public debate in a free public space before being recommended to large populations. ${ }^{47}$ That is, in a truly democratic world, new vaccines should not be treated as uncontroversial, prior to a dialogue that involves all diverging views of experts and

47 This question-raising concerns also many other issues on which the public receives no clear answer: if it is correct what an epidemiologist said during a (systemic) TV interview that, to stop the Omicron variant, the vaccine can be upgraded in a couple of weeks, why have the vaccines not been upgraded so many months now, to protect the vaccinated more fully from Delta? If the vaccine neither immunizes, nor blocks Covid-19 spread, but stimulates the immune system so that death or hospitalization be avoided, then how does it qualify to the term "vaccine" more than other "preparations" that also boost the immune system? Instead of modifying the term "vaccine" to make the new vaccine fitting, should the vaccine not be upgraded or another vaccine prepared to better fit the vaccine definition - not for nominalist purposes but for securing real and maximized benefits? If these vaccines are feared or dismissed by some people due to their mRNA technology, then why does the Western world, which loathes monopolies and purportedly values pluralism and variety (inter alia within the marketplace), not cater for its people the traditional anti-Covid vaccines that are elsewhere on offer? 
responses representative of all those affected by a new practice [19-23].

In the name of the problem-solving urgency of the limit situation and its overcoming for returning to previous financial and existential "normalcy", and in political efforts publicly to present the vaccine as a scientifically totally uncontroversial issue, controversies over these vaccines become increasingly glossed over and censored. In August 2021, Peter Singer used a problem-solving logic ${ }^{48}$ and an analogy with the imposition of seat-belt laws to argue in favour of mandatory Covid-19 vaccination. The analogy reflects faulty syllogism (strikingly reminiscent of the Logician's in Rhinoceros) in many ways, some of which were realized by Singer himself in the course of his interview and made him admit that the "situations are not identical". Seatbelts can be removed, though vaccines cannot once they are in the body. That the benefits of seat-belts outweigh the risks is more evident than concerning vaccines whose long-term side-effects are still unknown/untested. Singer's claim that the case for mandating vaccination is stronger than that of seat-belts because not using a seat-belt presents risks for oneself while not being vaccinated exposes to risk all others is contradictory: if the vaccine indeed protects from health hazards, as he stated, then, the unvaccinated risk their own safety, not that of the vaccinated. To the argument that the unvaccinated should be allowed to be responsible for themselves and face any personal risk that they are willing to undertake Singer responded with a view of a benevolent society, protective as a guardian angel: "we are not that hardhearted as a society", "not so callous" to tell them that you should not have a bed in a hospital then, since you refused to be vaccinated; and, this entails, for Singer, that mandating vaccination is justified! ${ }^{49}$ I do not question Singer's good intentions but good intentions have sometimes led to the worst complicities. Many good Germans who did not have a full picture of Mengele's horrific actions must also have had prudentialist arguments and protective, 'angelic' enthusiastic

48 To the question about why to force people to get vaccinated, Singer answered with a set of unsubstantiated and oversimplified claims that the unvaccinated present higher health risks for others. I have complicated this simplistic assumption elsewhere (Papastephanou, 2021), so I will not cover this ground again in this article. In fact, in the months that lapsed since the previous article, the situation in many countries where the vaccination has reached over 90 per cent and yet lockdowns were not avoided (while breakthrough cases were of alarming frequency and brought over lockdowns) has proven my claims right. Besides, many other people, some of them medical scientists, pharmacologists, etc., far more capable of complicating such assumptions than I am, had long before predicted that such assumptions would prove unsubstantiated and rushed.

49 Peter Singer in: https://www.youtube.com/ watch?v=ct83CQdb4wo\&ab_channel=SkyNewsAustralia One can think of all sorts of things that such a logic would render mandatory: to keep one's body below a certain weight, to have a specific lifestyle, to abstain from alcohol and smoking, people to pay fines when they let work stress them to harmful effect for health, etc. reactions to science's "progress". The protective guardian angel may be blind to a dreadful Doppelegänger: Todesengel. Despite the repeated historical warnings, contemporary society misses that the Engel (angel) is contained in Mengele.

Want it or not, unlike the response that other, more traditional vaccines received as they became consolidated and accepted in time, a significant minority that does not necessarily belong to the far-right anti-vaxxer group reacts to this new technology with unprecedented fervor and voices sensible concerns. Homeless as this minority currently is, it may become a strategic minority, manipulable by those who will offer to shelter it. Curiously, post-isms sensitive to minoritarian rights and societies proud of their "democratic" "progressivism" fail to see that, in any case, one's rights do not stand or fall on grounds of whether we like their ideologies or not. Moreover, totalitarianism may invite further, and reactive, totalitarian spirit: I can very well imagine, and I dread, that the Australian philosopher's position will make some people, who have post-modernly learned to think genealogically yet not anti-essentialistically, wrongly incriminate all Australian culture as productive of such positions: the related slogan will be "once colonial, always colonial!"; in Germany's and Austria's case, "once a Nazi, always a Nazi!" In Greece and Cyprus' case, "once dictatorship-generating, always dictatorship-generating!"

The pathos of distance, the gap that current policies will reproduce or deepen, which will be exploitable by expedient populists, echoes the following passage from Jeux de Massacre on minoritarian or group-specific lack of trust in authorities: "POLITICIAN My fellow citizens, I have gathered you here today to speak to you about the future of our city. I have disregarded the orders which outlaw public gatherings and I see that you have done the same by coming here in great numbers under the very noses of our present leaders. They want to keep us shut up in our homes and our fears. With the pretext of a mysterious sickness raging among us, and they are not above using any pretext whatsoever, using then the pretext of a plague, we have been immobilized, rendered impotent, paralyzed, dominated, and destroyed. [...] It is bad moral policy to remain confined, bad for us, but for our unscrupulous governors, it serves their purposes" (P. 73).

In Ionesco's dystopian universe, a totalitarian regime finds its mirror image in an opposition diversified to comprise equally complicit populist reactionaries and reformist modernizers.

"I wonder if this so-called mysterious disease is not one of their inventions? And why is it called mysterious indeed? It's to hide the real reasons behind it, the reasons I shall 
reveal to you today. Who benefits from the continuation of this epidemic?" (74).

"Of the seventeen councillors on duty in the city, only three have died. Compared to the deaths among the population, this figure is insignificant. And of the three councillors who have died, one supports our claims completely: he was an enemy of the Council President and a friend of the people. The other two were on-the-liners ... supporters of the present administration but half-heartedly and without conviction" (75).

Ionesco tackled conspiracy theories very early, yet not in any way that would have exculpated the regime. Nothing escapes Ionesco's critique and questioning:

"THIRD DOCTOR There is nothing inevitable about it [death]. Except, of course, when men of law have judged that certain citizens are to be condemned for crimes against humanity and country. Or except when the medical corps decides that society can no longer provide for the needs of everyone and therefore thirty, forty or fifty per cent of the population must be eliminated. In that case, the ones to go would be those and only those who believe in death for mystical reasons or those who fail to obey the laws of hygiene or who believe more in death than in life. We don't need any of these types. Good riddance!" (87) [24,25].

\section{Conclusion}

Vaccine-maniacs say nothing about the lack of better health systems which might diminish the death rate or about health systems impoverished either by neoliberal austerity measures or now by suspending the unvaccinated medical staff. Instead, they claim statistics. They overlook that such statistics may be affected in advance by failures to fill out yellow cards. Worse, they overlook that compulsory/forced vaccinations are not imposed on numbers or statistics but on human beings, singular, unique, who would not want to be the statistical deviation from the scientific achievement's success story.

Instead of the problem-solving option and the wake-upcall option being a drastic choice, I have, through the "limit situation" notion, argued for another possibility: warnings not only concerning automatisms of the past that should be overcome but also warnings against overcoming important automatisms of the past such as inhibitions concerning mandatory vaccinations. These are about to be lost in the problem-solving frenzy of (neo-)liberal misanthropic logics and oversimplifications.

"Symptoms create emergencies", writes one author, and "identity politics" is sometimes necessary for addressing "specific injustices such as prejudice against particular groups". Psychoanalysis aspires "to discern what stands behind symptoms: to remember that, where there are many external 'symptoms', there may be underlying organising psychological processes. If so, if lasting change is to occur, something else needs to be identified, at a deeper level than the symptoms, and perhaps quite different in kind from the symptoms" (Black, p. 12). I hope to have indicated that the very idiom of symptoms and emergencies involves political risks of the over-zeal to cure, that is, yet another symptom, a yet deeper pathology. I have elsewhere termed this risk "a medicalization of politics" and hinted at it in this article by discussing pandemic totalitarianisms, limit situations and forced vaccinations. I conclude with this passage from Ionesco's Jeux de Massacre:

"FOURTH WOMAN (to third) It's better to prevent than to cure.

FOURTH MAN (to THIRD) Nothing is really preventable.

THIRD WOMAN (to FOURTH) Nothing is really curable.

THIRD MAN (to FOURTH) Not even the predictable. FOURTH WOMAN (to THIRD) Not even the curable. FOURTH MAN (to THIRD) And even the predictable is not preventable.

THIRD WOMAN And in my opinion, the curable is the real poison" (P. 9).

\section{References}

1. Cole G (2021) COVID-19, Limit Experiences, and Undergoing the Situation: Therapeutic Implications for Pandemic Times. Journal of Humanistic Psychology 61(2): 190-197.

2. Artaud A (2013) Theatre and the plague. In: The theatre and its double. Corti V (Trans.). London: Alma Classics, pp: 9-22.

3. Ionesco E (1974) Jeux de Massacre (Killing Game). New York: Grove Press.

4. Ionesco E (1960) Rhinoceros. New York: Grove Press.

5. Jaspers K (1941) On My Philosophy.

6. Papastephanou M (2019) Political education in times of political apathy and extreme political pathos as global ways of life. Educational Studies in Japan 13: 81-95.

7. Papastephanou M (2021) Philosophy of Education in Times of Crises and Pandemics. Education Sciences 11(11): 687.

8. Jaspers K (1971) Psychologie der Weltanschauungen. Berlin: Springer Verlag. 
9. Jaspers K (1973) Philosophie II. Existenzerhellung, vierte Auflage. Berlin: Springer.

10. Jaspers K (1947) Von der Wahrheit. München: Piper.

11. Black DM (2021) The Covid Crisis: "A Wake-up Call" to What?. Free Associations: Psychoanalysis and Culture, Media, Groups, Politics, 81-82: 11-17.

12. Jaspers K (1970) Philosophy: Vol. II. Ashton EB (Trans.). Chicago: University of Chicago Press.

13. Gordon RD (2000) Karl Jaspers: Existential philosopher of dialogical communication. Southern Journal of Communication 65(2-3): 105-118.

14. Jaspers, K. (1962) Kant: From the great philosophers. $1^{\text {st }}$ (Vol.), Arendt H (Ed.), Manheim R (Trans.). San Diego, CA: Harvest/HBJ.

15. Gatta G (2008) Theorizing among ruins: Karl Jaspers and the political theory of boundary situations (Doctoral dissertation, University of Minnesota).

16. Wolin R (1992) Carl Schmitt: The conservative revolutionary habitus and the aesthetics of horror. Political Theory 20(3): 424-447.

17. Fuchs $\mathrm{T}$ (2013) Existential vulnerability: Toward a psychopathology of limit situations. Psychopathology
46(5): 301-308.

18. Ratcliffe M (2021) Disorientation, Distrust, and the Pandemic. Global Discourse: An interdisciplinary journal of current affairs 11(1-2): 1-5.

19. Freire P (2000) Pedagogy of the oppressed. New York: Continuum.

20. Jaspers K (1967) Philosophische Aufsätze. Frankfurt am Main und Hamburg: Fischer Bücherei.

21. Mundt C (2014) Jaspers concept of "limit situation": Extensions and therapeutic applications. In: Karl Jaspers' Philosophy and Psychopathology. New York: Springer.

22. Papastephanou M (2009) Method, Philosophy of Education and the Sphere of the Practico-Inert. Journal of Philosophy of Education 43(3): 451-469.

23. Papastephanou M (2011) The 'cosmopolitan'self does her homework. Journal of Philosophy of Education 45(4): 597-612.

24. Papastephanou M (2017) Reflections on the European promise. New German Critique 44(2): 133-162.

25. Salamun K (1988) Moral Implications of Karl Jaspers' Existentialism. Philosophy and Phenomenological Research 49(2): 317-323. 